This study aimsto scientifically substantiate the influence of the quality, size of carrot roots, as well as storage techniques, on safety that couldprolong their consumption.

The research into carrot roots has not been developed properly. In this regard, it is important to conduct comprehensive studies of objective indicators that exert the greatest impact on the intensity of natural weight loss of carrot roots and their preservation. The study reported here aimed to scientifically substantiate the influence of the quality, size of carrot roots, as well as storage techniques, on safety, which could allow them to be consumed longer.

It has been theoretically substantiated and experimentally confirmed that the longest storage period of 206 days with a commercial yield of $89.27 \%$ characterized large root crops. The output of marketable products of medium root crops was $86.56 \%$, small ones after 161 days - 80.30\%. Compared with large root crops, the shelf life of both small and mechanically damaged carrots decreased by 46 days, and the yield of marketable products decreased by 9.0 and $11.1 \%$, respectively. Carrot roots damaged by pests were preserved almost the same as chopped ones. On average, over 191-192 days of storage, the yield of marketable products amounted to 83.43 and $83.90 \%$, respectively. The shortest shelf life (142) and the worst preservation (68.34\%)were observed in carrots with a torn peel, due to a large number of diseased root crops $(18.53$ and defective ones $(6.85 \%)$.

Storage of carrots in boxes at a permanent storage facility with forced-air and exhaust natural ventilation turned out to be ineffective. The yield of marketable products amounted to $85.5 \%$. The highest safety of 96.3-94.3\% was observed when the roots were stored in plastic bags and perforated bags, respectively. A greater yield of marketable products is provided by bags with a capacity of $5 \mathrm{~kg}$. It was found that the storage in cardboard boxes and paper bags contributed to the development of microorganisms. The number of affected root crops ranged from 2.4 to $2.8 \%$

Keywords: roots, carrot, product output, preservation, weight loss
UDC 635.36:631

DOI: $10.15587 / 1729-4061.2022 .251785$

\title{
DETERMININGCARROT PRESERVATION DEPENDING ON THE ROOT QUALITY AND SIZE, AS WELL AS ON STORAGE TECHNIQUES
}

L u d m i l a Pus i k
Correspondingauthor

Doctor of Agricultural Sciences, Professor Department of Horticulture and Storage of Crop Products*

E-mail: ludmilap@gmail.com

Vladimir Pusik

Doctor of Agricultural Sciences, Professor Department of Ecology and Biotechnological*

Veronika Bondarenko

$\mathrm{PhD}$, Associate Professor

Department of Horticulture and Storage of Crop Products*

Lud mila Gaevaya $\mathrm{PhD}$, Teacher

Department of Horticulture and Storage of Crop Products*

Natalja Kyruchina

PhD, Senior Researcher

Laboratory of Selectionof Biennial and Rare Crops**

O leks andr Kuts

Doctor of Agricultural Sciences, Senior Researcher, Director**

Galina Slobodianyk

$\mathrm{PhD}$, Associate Professor***

O Iga Nakloka

$\mathrm{PhD}$, Associate Professor***

*State Biotechnological University

Alchevskykh str., 44, Kharkiv, Ukraine, 61002

** Institute of Vegetable and Melon Growing of the National Academy

of Agrarian Sciences of Ukraine

Institutska str., 1, Selektsionnoe vill., Kharkiv dist., Kharkiv reg.,

Ukraine, 62478

*** Department of Vegetable Growing

Uman National University of Horticulture Institutska str., 1, Uman, Ukraine, 20305

Received date 14.12.2021 Accepted date 18.02.2022 Published date 27.02.2022
How to Cite: Pusik, L., Pusik, V., Bondarenko, V., Gaevaya, L., Kyruchina, N., Kuts, O., Slobodianyk, G., Nakloka, O. (2022). Determiningcarrot preservation depending on the root quality and size, as well as on storage techniques. Eastern-European Journal of Enterprise Technologies, 1 (11 (115)), 26-32. doi: https://doi.org/10.15587/1729-4061.2022.251785

\section{Introduction}

The problem of vegetable preservation is quite relevant because during the acceptance of products from producer to consumer the losses can reach $30 \%$ or more. These losses can be significantly reduced by following the rules of use and product care during storage and transportation to the consumer. The main causes of product loss are, first, weight loss during respiration, water evaporation, and germination. Losses of water and dry matter are from 10 to $35 \%$ of the to- 
tal weight loss. The maximum amount of water loss is different for each type of raw material. Carrots, beets in bunches with leaves lose $3-4 \%$, carrot roots, potatoes $-7-8$. If the maximum level is exceeded, the product becomes unfit for sale. Second, the losses that are associated with the disease. Their volume is difficult to predict but, in the case of mass distribution, they can reach $100 \%$. Mechanical damage can also cause serious consequences. Weight loss during storage depends on the size of the food organ of vegetables. Very large roots of radish become woody, hollow, loose, and unsuitable for preservation. Greens turn yellow, stems, leaves and petioles become coarse, inedible [1].

For the base for rating the quality of fruits and vegetables, an important role belongs to standardization. The standard is a guarantor of product quality, an evaluation toolbut not a regulator of laying quality vegetables for storage. None of the currently approved standards for fresh fruit and vegetables harvested and stored provides $100 \%$ quality. A number of tolerances regulating the standard actually reduce it by 5 or even more percent. Due to the fact that fruits and vegetables and other places of long-term storage of vegetables come mainly with quality that does not meet the requirements of standards, the safety of such products is low. During longterm storage of low-quality products, losses increase, which leads to increased costs. Studies of the safety of vegetables, depending on their quality when stored, are fragmentary. There are standards for natural weight loss, while no standards for reducing the quality of vegetables depending on the quality of laying exist.

Studies into this arearegarding carrot roots have not been properly developed. In this regard, conducting comprehensive studies of objective indicators that have the greatest impact on the intensity of natural weight loss of carrots, their preservation, is relevant.

Therefore, there is a need to evaluate the existing most common method of storing carrots at stationary facilities and improve it to increase the preservation of root crops without changing the established storage technology. Early prediction of weight loss makes it possible to determine the theoretical shelf life of vegetables before storage.

\section{Literature review and problem statement}

In paper [2], it was noted that the best temperature for storing vegetable roots is from $0{ }^{\circ} \mathrm{C}$ to minus $1{ }^{\circ} \mathrm{C}$. Permissible deviations in one direction or another is up to $0.5^{\circ} \mathrm{C}$. With a further decrease in temperature, the roots may freeze, and with an increase - weight loss increases as well asmicrobiological damage. Relative humidity should be high - about $95 \%$. This is especially true of carrots and other delicate roots, which easily lose water and, as a result, resistance to phytopathogenic microflora. Fogging of root crops, as well as other vegetables, is undesirable and should be prevented during storage. But the author provides summary information for the mode of roots storage. Under such conditions, studies of the preservation of parsnip roots were performed [3]. But there are unresolved issues related to the quality of root cropslaid for storage. The study of carrot preservation depending on its quality under such conditions was not conducted.

It was found in [4] that during the storage of root crops, an increased concentration of carbon dioxide is favorable.
However, its content should not exceed 3-5\%. At this concentration, the development of microorganisms is inhibited, slows down the intensity of respiration and other metabolic processes, prolongs the period of forced rest, germination is delayed, weight loss is reduced. Therefore, it is very promising to store carrots and other roots in different types of packaging made of polymer film, leaky or perforated. If the content of $\mathrm{CO}_{2}$ in these packages increases above the optimal concentration, fermentation and accumulation of incomplete oxidation products (ethanol, acetaldehyde) are observed. Due to the decomposition of pectin substances, root tissue tissues turn into a pulpy mass. However, scientists do not specify the capacity for storing roots. Note that research into the storage of carrots in packages of different capacities has not been conducted.

Good results are obtained when claying the produce. The roots are loaded into a bath with a creamy mess and then transferred to boxes with holes. The layer of clay that remains on the roots dries and forms a thin "cover". It protects them from moisture evaporation and prevents wilting, as well as the spread of disease [5]. This method of root preparation has not been widely used. The reason for this is the objective difficulties associated with water consumption and energy for drying. In addition, the buyer prefers pure roots, without the presence of soil or clay.

The modern technique of carrot storing is in a modified gaseous medium using unsealed plastic bags, which are made of a film $150-200 \mu \mathrm{m}$ thick with a capacity of $30-50 \mathrm{~kg}$. Bags are placed in refrigerated storage on racks vertically, without tying the neck. Such packaging does not accumulate excess $\mathrm{CO}_{2}$ and does not condense water vapor, which helps extend shelf life, reduce losses, preserve turgor and high-quality products [6]. But the weight of roots and their initial quality is also not studied.

Studies of the preservation of some vegetables depending on the size of the food organ were conducted. In [7], it was noted that sorting and calibration of vegetables affect the safety of tomatoes. In [8], it is recommended to collect roots, cabbage by the size of the food organ or as needed.

It was established that the safety of zucchini depends on the size of the fruit. Under the conditions of a raw material site at a day temperature of $26 \ldots 30^{\circ} \mathrm{C}$, fruits with a diameter of more than $8 \mathrm{~cm}$ are stored for $13-18$ days, with a diameter of $4.5-6.0 \mathrm{~cm}$ for 2-6 days. At a temperature of $5 \pm 1{ }^{\circ} \mathrm{C}$, fruits with a diameter of $4.5-6.0 \mathrm{~cm}$ are stored for 5 days, with a diameter of $6.1-8.0 \mathrm{~cm}$ for 13-16 days, a mixture of fruits with a size of 10-12 days, and large non-standard fruits $(8.1-10.0 \mathrm{~cm})-18-21$ days. The loss of fruit weight during storage at a temperature of $5 \pm 1{ }^{\circ} \mathrm{C}$ by $42 \%$ depends on their size. The yield of marketable products by $22 \%$ depends on the size of the fruit [9].

Under normal refrigeration conditions, cucumbers in an open box retain their properties for two days, greater natural losses are observed in greens with a length of 91-110 mm than in the mixture. Cucumbers are stored for almost two weeks with almost no losses at a temperature of $5 \pm 1{ }^{\circ} \mathrm{C}$ in boxes with plastic wrap or in plastic bags with a capacity of $20 \mathrm{~kg}$. The average daily loss of fruits, when stored in plastic bags, did not exceed $0.08-0.10 \%$ [10]. However, similar studies of the preservation of carrot roots have not been conducted. An option to overcome these difficulties may be the results of this study.

Methods and techniques of fruit and vegetable storage at the present stage of science development remain mostly quite conservative. However, new research is emerging in a variety of fields to develop new ways to store fresh vegetables. 
Analysis of modern scientific literature allows us to identify storage methods that are actively used in practice. In [11], it is noted that after harvesting vegetables, they remove the soil from the vegetables. Cold running water is used to clean vegetables. Then they dry them well to prevent rot. It is possible to dry vegetables in the sun. The top of the roots is cut about half an inch. It is not recommended to wax roots for storage. It was found that unwashed roots stored in the open boxes were affected by the disease by $0.7 \%$ more than washed. Storage of washed roots in plastic bags increased their damage by almost 3.5 times than unwashed.

There is a developed method of storing vegetables that involves loading them into special containers for pre-treatment with ozone at a concentration of $45-50 \mathrm{mg} / \mathrm{m}^{3}$ for a specified time [12]. Such a method of processing vegetables requires certain equipment, which is not economically feasible. Ozone treatment may not always be safe.

There is a developed method of storage and transportation of fruits and vegetables in special boxes with sterilization, which reduces pesticide residues [13]. Storage in such a package requires sterilization, which is fundamentally impossible in production conditions. The cost of such packaging is increasing, which makes the relevant research with carrots economically impractical.

The structure of vegetables is a hallmark of the species and their varieties. Carrot roots have thin integumentary tissues, have more lentils, more intensely evaporate moisture. The condition of integumentary tissues is determined not only by the type and variety of vegetables but also by growing conditions, the degree of ripeness of the size of the food organ. Vegetables grown in cold and rainy summers are less formed, their integumentary tissues are thin and contain less cutin, wax, or suberin. In [14], it was found that the period of ripening of guam fruits grown in mountainous areas is delayed, the integumentary tissues are insufficiently formed. This leads to the fact that the losses from water evaporation increase significantly. The condition of the integumentary tissues depends on the degree of ripeness and for root crops - the size of the root. Studies of the preservation of carrot roots are scarce. All this suggests that it is appropriate to conduct this study.

The largest share of activated losses (80-90\%) accounts for microbiological and physiological diseases. An important physiological factor influencing the development of microbiological and physiological diseases is the natural resistance of vegetables to microorganisms - pathogens and adverse external conditions that cause physiological disorders. Other biological factors: varietal characteristics, growing conditions, physiological state of vegetables - can only strengthen or weaken the natural stability, participate in its creation and maintenance [15].

Thus, the loss of fruit and vegetable produce is a function of many arguments. Determining this indicator is of great scientific and practical importance. Knowing and regulating the factors that affect the weight loss of carrot roots during storage, one can significantly reduce them and extend the shelf life.

Studies to determine the preservation of carrot roots depending on the initial quality, size of roots, methods of storage are scarce, are disparate and generalized.

\section{The aim and objectives of the study}

The study aims to determine carrotpreservation depending on the root quality before storage, the size,as well as storage techniques, which could extend the duration of carrot consumption.

To accomplish the aim, the following tasks have been set:

- to determine the effect of initial quality on the preservation of carrot roots;

- to study the dynamics of natural weight loss depending on the size of the root;

to carry out a comparative assessment of carrot preservation depending on the storagetechnique.

\section{The study materials and methods}

The study was conducted with a variety of carrots Shantene skvyrska. The product weight was divided into three fractions: version 1 are roots weighing 150-180 g (large), version 2 - weighing 100-140 g (medium), version 3 - weighing 60-90 g (small). A mixture of root crops was taken as a control. Certain defects are allowed in the standards for vegetable products. For carrots, these are deviations in shape, mechanical damage, damage by agricultural pests. These types of damage are biological defects. Therefore, the relevant variants of the experiment were identified: 4 -distorted roots; 5 - mechanically damaged; 6 - cracked roots; 7 - damaged by pests; 8 - with peeled skin.

In the first experiment, carrots sorted into fractions by root sizeand defects were stored in bulk, in boxes with a capacity of $5 \mathrm{~kg}$ in uncooled storage with supply and exhaust ventilation. The preservation of root crops was established.

The second experiment studied the dynamics of natural weight loss depending on the size of the root crop. Observations were performed visually, 1 month after storage. To determine the weight loss during storage of root crops, each accounting sample (weighing $5 \mathrm{~kg}$ ) was weighed, numbered, recorded in the journal with the characteristics of the quality of root crops.

Natural weight loss was determined by the formula

$$
X=\frac{A-B}{A} \cdot 100,
$$

where $X$ is the weight loss, $\% ; A$ is a produce mass when laying for storage, $\mathrm{g} ; B$ is a mass of produce at the end of the storage, g.

In the third experiment, the roots were placed in storage with supply and exhaust ventilation in open boxes (control), in cardboard boxes, in plastic bags, plastic bags with perforations, in paper bags. The safety of carrots was determined in a storage facility without artificial cooling, depending on the type of container.

The duration of storage finished when the natural weight loss reached $10 \%$ or more and the products showed signs of disease and physiological disorders. The presence of pathogens was detected under a microscope. The absolute shortage is a product that has completely lost its consumer properties and whose defects cannot be eliminated.

The scientific assumptionwas put forward to extend the shelf life of carrots depending on the quality of the roots before storage, their size, and storage techniques.

The data presented in this paper are the average value from three measurements. Statistical analysis was performed using Microsoft Excel 2007 (USA). Differences were considered statistically significant at the significance level $\alpha=0.05$. 


\section{Results of studying carrot roots preservation}

\section{1. Determining the effect of the initial quality on} the carrot roots preservation

The results of studying the yield of standard production depending on the size, shape, and character of mechanical damage on the preservation aregiven in Table 1.

Table 1

The yield of marketable carrots depending on the size, shape, and type of rootdamage

\begin{tabular}{|c|c|c|c|c|c|c|c|}
\hline $\begin{array}{c}\text { Ver- } \\
\text { sion }\end{array}$ & $\begin{array}{c}\text { Size, shape, } \\
\text { and type } \\
\text { of root- } \\
\text { damage }\end{array}$ & $\begin{array}{c}\text { Storage } \\
\text { time }\end{array}$ & $\begin{array}{c}\text { Natural } \\
\text { weight } \\
\text { loss }\end{array}$ & $\begin{array}{c}\text { Dam- } \\
\text { aged by } \\
\text { disease }\end{array}$ & $\begin{array}{c}\text { Abso- } \\
\text { lute } \\
\text { defect }\end{array}$ & $\begin{array}{c}\text { Gener- } \\
\text { al loss }\end{array}$ & $\begin{array}{c}\text { Yield } \\
\text { of pro- } \\
\text { duce }\end{array}$ \\
\hline 1 & Medium & 205 & 6.04 & 5.18 & 2.22 & 13.44 & 86.56 \\
\hline 2 & Small & 161 & 8.21 & 5.49 & 6.00 & 19.70 & 80.30 \\
\hline 3 & Large & 206 & 5.25 & 3.87 & 1.61 & 10.73 & 89.27 \\
\hline 4 & Distorted & 207 & 6.53 & 5.59 & 2.91 & 15.03 & 84.97 \\
\hline 5 & $\begin{array}{c}\text { Defected } \\
\text { mechani- } \\
\text { cally }\end{array}$ & 161 & 6.64 & 10.21 & 4.97 & 21.82 & 78.18 \\
\hline 6 & Cracked & 197 & 6.59 & 6.13 & 3.38 & 16.10 & 83.90 \\
\hline 7 & $\begin{array}{c}\text { Damaged } \\
\text { by pests }\end{array}$ & 192 & 6.84 & 6.23 & 3.50 & 16.57 & 83.43 \\
\hline 8 & $\begin{array}{c}\text { With } \\
\text { peeled skin }\end{array}$ & 142 & 6.28 & 18.53 & 6.85 & 31.66 & 68.34 \\
\hline
\end{tabular}

It was established that large roots had the longest shelf life of 206 days with the yield of marketable products of $89.27 \%$. They were less affected by disease and had the lowest daily weight loss $(0.025 \%)$. Average root crops were 1.4 times more affected by diseases than large ones in 205 days of storage. Their daily weight loss was $0.029 \%$. The yield of marketable products was $86.56 \%$. Small and mechanically damaged ones were much worse preserved. The duration of their storage was 161 days. Their daily losses were 1.9 times greater than the average, respectively, by 1.7 times due to natural loss -3.4 times of defect.

Carrot roots in version 8 were stored in the same way as 7. On average, during 191-192 days of storage, the yield of marketable carrots with peeled skin was $83.43 \%$ and cracked roots $83.90 \%$.

Thus, it is possible to extend the shelf life of carrots by sorting and calibrating the roots before storage.
It is possible to predict the loss of root mass during storage by regression analysis. It was found that weight loss depending on the size of the vegetable is described by the regression equation given in Table 3 .

Table 2

The correlation of yield of marketable product, shelf-life, weight loss, structure loss

\begin{tabular}{|c|c|c|c|c|c|c|}
\hline $\begin{array}{c}\text { Fac- } \\
\text { tors }\end{array}$ & $x_{1}$ & $x_{2}$ & $x_{3}$ & $x_{4}$ & $x_{5}$ & $x_{6}$ \\
\hline $\mathrm{x}_{1}$ & 1 & 0 & 0 & 0 & 0 & 0 \\
\hline $\mathrm{x}_{2}$ & 0.924315 & 1 & 0 & 0 & 0 & 0 \\
\hline $\mathrm{x}_{3}$ & -0.28696 & -0.44421 & 1 & 0 & 0 & 0 \\
\hline $\mathrm{x}_{4}$ & -0.95034 & -0.80387 & -0.0198 & 1 & 0 & 0 \\
\hline $\mathrm{x}_{5}$ & -0.92176 & -0.96358 & 0.604807 & 0.758158 & 1 & 0 \\
\hline $\mathrm{x}_{6}$ & -1 & -0.92432 & 0.286962 & 0.950337 & 0.921758 & 1 \\
\hline
\end{tabular}

Note: $x_{1}$ - yield of produce; $x_{2}$ - storage time, days; $x_{3}-$ natural weight loss, $\% ; x_{4}$ - disease damage, $\% ; x_{5}$ - absolutely defected, $\%$; $x_{6}$ - general losses, $\%$.

The trend line was used for analysis (estimation) of regression analysis errors. The accuracy of regression analysis was determined by the value of $R^{2}$. According to $R^{2}=0.297-0.636$ on the linear dependence of the weight loss of carrot roots on their size. The curvilinear correlation dependence of the second order of root mass loss $R^{2}=0.851-0.991$ is more reliable.

Table 3

Regression equation for the dependence of weight loss by roots on size

\begin{tabular}{|c|c|c|c|c|}
\hline $\begin{array}{c}\text { Root } \\
\text { size }\end{array}$ & $\begin{array}{c}\text { Regression } \\
\text { equation of linear } \\
\text { dependence }\end{array}$ & $R^{2}$ & $\begin{array}{c}\text { Regression equation of } \\
\text { curvilinear dependence }\end{array}$ & $R^{2}$ \\
\hline Control & $Y=-0.2 x+1.7$ & 0.636 & $Y=0.091 x^{2}-0.837 x+2.55$ & 0.917 \\
\hline Small & $Y=0.411 x+0.76$ & 0.297 & $Y=0.385 x^{2}-2.288 x+4.36$ & 0.851 \\
\hline Medium & $Y=-0.168 x+1.61$ & 0.448 & $Y=0.126 x^{2}-1.056 x+2.79$ & 0.991 \\
\hline Large & $Y=-0.157 x+1.43$ & 0.497 & $Y=0.103 x^{2}-0.882 x+2.4$ & 0.958 \\
\hline
\end{tabular}

It is established that the size of root crops affects the duration of the state of forced rest. From the end of January, weight loss begins to increase, which indicates the release of roots from dormancy.

\section{2. Natural weight loss depending on a} root's size

Natural weight loss of carrot roots during the storage period occurs unevenly. At the beginning of storage,it was quite high, then it gradually decreases. During the period of forced rest - the smallest, and in March, due to the intensification of life processes, begin to grow (Fig. 1).

The correlation between the yield of marketable products by shelf life, weight loss, loss structure is given in Table 2. It is established that there is a close linear relationship between the shelf life and the yield of marketable carrot products: the correlation coefficient is 0.924315 .

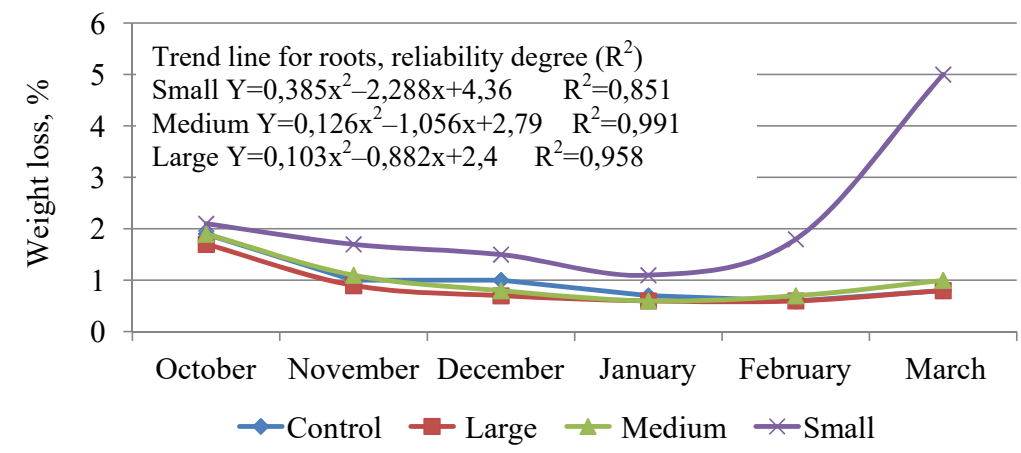

Fig. 1. The dynamics of weight loss of carrot roots depending on their size, \% 
5. 3. Comparative assessment of carrot preservation depending on the storage technique

In the literature,one can find recommendations for storing roots in different containers: wooden and cardboard boxes, paper and plastic bags, containers [3-6]. A comparative assessment of different types of containers when storing carrots shows that the highest weight loss was demonstrated by carrots, which were stored in wooden boxes in bulk (Table 4).

Carrots in a storage facility without artificial cooling when storedover 6 months in wooden boxes lost much moisture but wereinsignificantly affected by diseases. The content of absolutelydamage produce among the studied containers was high $-1.2 \%$.

In a permanent storage facility with a natural supply and exhaust ventilation, the storage of carrots in boxes proved to be ineffective (Table 2). The yield of marketable products was $85.5 \%$.

Table 4

Carrot preservation at a storage facility without artificial cooling depending on the type of container, $\%$

\begin{tabular}{|c|c|c|c|c|}
\hline Container type & $\begin{array}{c}\text { Weight } \\
\text { loss }\end{array}$ & $\begin{array}{c}\text { Affected } \\
\text { by disease }\end{array}$ & $\begin{array}{c}\text { Totally } \\
\text { damaged }\end{array}$ & $\begin{array}{c}\text { The yield } \\
\text { of healthy } \\
\text { produce }\end{array}$ \\
\hline $\begin{array}{c}\text { Wooden boxes } \\
\text { (control) }\end{array}$ & 11.7 & 1.6 & 1.2 & 85.5 \\
\hline Cardboard boxes & 5.8 & 6.2 & 0.3 & 87.7 \\
\hline Plastic bags & 0.7 & 2.8 & 0.2 & 96.3 \\
\hline $\begin{array}{c}\text { Polyethylene } \\
\text { perforated bags }\end{array}$ & 2.7 & 2.4 & 0.6 & 94.3 \\
\hline Paper bags & 8.9 & 3.3 & 2.2 & 85.7 \\
\hline
\end{tabular}

The highest preservation of $96.3-94.3 \%$ of carrots was demonstrated when they were stored in plastic bags and perforated bags, respectively. At the end of storage, the roots retained turgor, bright color, good appearance but storage under these techniques in artificially uncooled storage, where temperature fluctuations often occur leads to increased damage to root crops by disease. It was established that storage in cardboard boxes and paper bags contributed to the development of microorganisms. The number of affected roots ranged from 2.4 to $2.8 \%$.

The preservation of carrots in a plastic bag is affected by its capacity, as well as the roots that are put in itwashed or contaminated with soil (Table 5). It was found that unwashed roots were less affected by diseases but germinated more intensively.

The preservation of washed carrot roots averages $91.69 \%$. The yield of unwashed roots is $94.47 \%$.

It was established that the loss of root mass depends on the capacity of the bag.

The short-term change in the air temperature inside the storage does not significantly affect the change in the temperature inside the plastic bag while the spring steady rise in storage temperature is faster than in bags.

\section{Discussion of results of carrot preservation depending} on the quality, size of roots, as well as storage techniques

It was experimentally determined that the quality of roots affects the shelf life and the amount of weight loss. Compared to large roots, the shelf life of small and mechanically damaged carrots decreased by 46 days and the yield of marketable products decreased by 9.0 and $11.1 \%$, respectively (Table 1). Losses over a day of storage of small and mechanically damaged roots were 0.122 and $0.136 \%$, which is 1.9 and 2.1 times more than the average. Root crops weighing $60-90 \mathrm{~g}$ lose weight more intensively due to the processes of respiration and evaporation of moisture due to the thin cover tissue. There is a loss of turgor and self-protective properties. As a result, roots weighing 150-180 g by $3.82 \%$ while the weight of $60-90 \mathrm{~g}$ by $5.49 \%$. A larger number of roots with signs of microorganisms was in mechanically damaged ones, $10.21 \%$.

All kinds of mechanical damage contribute to the penetration of microorganisms, which leads to disease and evaporation of moisture. For the little ones, mechanically damaged, and peeled roots, a common feature is a high respiration rate.

Study [16] reports methods for measuring the internal and external quality characteristics of vegetables, such as size and shape, taste, texture, and no defects. Different methods are organized according to their physical principles of measurement.

In paper [17], it is proposed to treat roots with ozone to improve the safety of injured and withered roots. Treatment under optimal conditions with an ozone-air mixture or ozonated water severely damaged roots provides an average of 35-day storage reduction: the formation of rotten mass by $70 \%$, weight loss of $20-30 \%$, sugar losses by $30-40 \%$, compared to control. The use of ozone-dried root crops (up to $15 \%$ moisture loss) promotes the formation of rotten mass by an average of $30-40 \%$. After 55 days of storage, weight loss is reduced by $15-25 \%$, sugar losses by $20-30 \%$.

Similar studies are reported in [18]. Late-ripening radishes at $0{ }^{\circ} \mathrm{C}$ in plastic bags with a capacity of $5-10 \mathrm{~kg}$ can be stored until February. The study of the preservation of the roots of beets was carried out in [19], radish - [20], uterine roots - in [21]. Similar studies are described in [22]. The greatest weight loss during carrot storage was observed for perforated bags stored under retail conditions $(2.3 \%)$ and 
cold conditions $(1.4 \%)$. The weight loss was below $0.34 \%$ for all other packages with different combinations of perforation and storage. Carrots in laser and needle perforated packaging stored in cold conditions had the highest odor and terpene aroma. The percentage of diseased carrots was highest in laser-perforated packaging stored in retail. The experiment showed that the quality of carrots is best maintained in perforated packages with a needle. A gaseous atmosphere close to the air is created. This reduces weight loss, ethanol and disease are not formed. Research into the development of new technologies to improve the post-harvest processing of fresh fruit and vegetables is very important, as well as products with minimal processing. The phenomenon of abiotic stress hormesis in fresh vegetables shows the potential for the use of protective compounds, which can reduce disease during post-harvest storage. Protective films extend shelf life and increase the content of substances able to promote health [23].

At present, polymers derived from petroleum are widely used for packaging material. This situation is a matter of concern for environmental pollution. In the natural environment, polyethylene decomposes for more than 200 years. The limitation of this study is that Europe began to struggle with plastic reality 3 years ago. Then the directive was adopted, which obliges EU countries to limit the use of polyethylene. Therefore, by next year the amount of plastic used should be halved. The European Union wants to ban plastic bags altogether disposable tableware, straws, etc. This initiative has already been supported by more than 250 companies of well-known brands. The production of biodegradable bionatural film paves the way for the development of more environmentally friendly alternatives including polysaccharides and polypeptides. The use of these food biomacromolecules in addition to fruits and vegetables provides appropriate packaging with appropriate physical and mechanical properties as well as unique sensory and nutritional characteristics [24]. In this aspect, we envisage further research.

\section{Conclusions}

1. It was determined that the longest shelf life of 206 days with a high yield of marketable products $89.27 \%$ characterized large roots. The yield of marketable products of medium-sized root crops was $86.56 \%$, small ones over 161 days $-80.30 \%$. Pest-damaged carrot roots were stored almost in the same way, as well as cracked. On average, during 191-192 days of storage, the yield of marketable products was 83.43 and $83.90 \%$, respectively. The shortest shelf life (142 days) and the worst shelf life of $68.34 \%$ are observed in carrots with peeled skin.

2. Natural losses of carrot root mass in the first month of storage were quite high, $1.7-2.1 \%$, in the period of forced rest - decrease to 0.6-1.1, and in March, in connection with the intensification of life processes, they begin to grow $0.8-5.0$ depending on the size of the root crop.

3. Storage of carrots in boxes proved to be ineffective in a permanent storage facility with natural supply and exhaust ventilation. The yield of marketable products was $85.5 \%$. The highest preservation of $96.3-94.3 \%$ of carrots was when stored in plastic bags and perforated bags, respectively. At the end of storage, the roots stored turgor, bright color, good appearance. It was determined that storage in cardboard boxes and paper bags contributed to the development of microorganisms. The number of affected roots ranged from 2.4 to $2.8 \%$.

\section{Acknowledgment}

Our sincere gratitude to the graduates and laboratory assistants of the Department of Agrotechnology and Ecology of Petro Vasylenko KhNTUSG (Kharkiv, Ukraine) for their help in conducting field experiments, as well asthe preparation of produce for storage.

\section{References}

1. Kumar, D., Kalita, P. (2017). Reducing Postharvest Losses during Storage of Grain Crops to Strengthen Food Security in Developing Countries. Foods, 6 (1), 8. doi: https://doi.org/10.3390/foods6010008

2. Storage Life of Vegetables. Available at: https://extension.sdstate.edu/storage-life-vegetables

3. Pusik, L., Pusik, V., Lyubymova, N., Bondarenko, V., Rozhov, A., Sergienko, O. et. al. (2019). Preservation of parsnip root vegetable depending on the degree of ripeness, varietal features, and storage techniques. Eastern-European Journal of Enterprise Technologies, 1 (11 (97)), 34-41. doi: https://doi.org/10.15587/1729-4061.2019.155313

4. Alam, T. (2021). Packaging and Storage of Fruits and Vegetables. Emerging Trends. Apple Academic Press, 326. doi: https:// doi.org/10.1201/9781003161165

5. Prusky, D., Alkan, N., Mengiste, T., Fluhr, R. (2013). Quiescent and Necrotrophic Lifestyle Choice During Postharvest Disease Development. Annual Review of Phytopathology, 51 (1), 155-176. doi: https://doi.org/10.1146/annurev-phyto-082712-102349

6. Juneja, V. K., Dwivedi, H. P., Yan, X. (2012). Novel Natural Food Antimicrobials. Annual Review of Food Science and Technology, 3 (1), 381-403. doi: https://doi.org/10.1146/annurev-food-022811-101241

7. Arah, I. K., Ahorbo, G. K., Anku, E. K., Kumah, E. K., Amaglo, H. (2016). Postharvest Handling Practices and Treatment Methods for Tomato Handlers in Developing Countries: A Mini Review. Advances in Agriculture, 2016, 1-8. doi: https:// doi.org/10.1155/2016/6436945

8. Albert, S. Vegetable Harvest Times. Available at: https://harvesttotable.com/vegetable_harvest_times/

9. Koltunov, V. A., Puzik, L. M. (2007). Porivnialna otsinka sposobiv zberihannia plodiv kabachka. Ovochivnytstvo i bashtannytstvo, $53,354$.

10. Koltunov, V. A., Puzik, L. M., Vakulenko, L. M. (2006). Vplyv rozmiru ploda na zberezhenist kabachkiv, dyni, ohirkiv. Sbornik nauchnyh rabot Krymskogo gosudarstvennogo agrarnogo universiteta, 93, 56-60.

11. Waitrovich, B. (2014). Storing root vegetables. Michigan State University Extension. Available at: https://www.canr.msu.edu/ news/storing_root_vegetables 
12. Chen, C., Wang, W., Jia, N. (2010). Pat. No. CN 201849811 U. Fruit and vegetable storage-transportation fresh-keeping box with functions of sterilizing and degrading pesticide residue. declareted: 11.11.2010; published: 06.01.2011. Available at: http://www.google.com.pg/patents/CN201849811U?cl=en

13. Chen, C., Wang, W., Jia, N. (2010). Pat. No. CN 102001490 (A). Fruit and vegetable storage and transportation fresh-keeping box with functions of sterilization and pesticide residue degradation. declareted: 11.11.2010; published: 04.06.2011. Available at: https:// patents.google.com/patent/CN102001490A/en

14. Parra-Coronado, A., Fischer, G., Camacho-Tamayo, J. H. (2015). Development and quality of pineapple guava fruit in two locations with different altitudes in Cundinamarca, Colombia. Bragantia, 74 (3), 359-366. doi: https://doi.org/10.1590/1678-4499.0459

15. Global Initiative on Food Loss and Waste Reduction (2015). FAO. Available at: https://www.fao.org/3/i4068e/i4068e.pdf

16. Nicolaï, B. M., Defraeye, T., De Ketelaere, B., Herremans, E., Hertog, M. L. A. T. M., Saeys, W. et. al. (2014). Nondestructive Measurement of Fruit and Vegetable Quality. Annual Review of Food Science and Technology, 5 (1), 285-312. doi: https:// doi.org/10.1146/annurev-food-030713-092410

17. Kapustnikov, Yu. A. (2003). Razrabotka sposobov povysheniya sohrannosti massy i kachestva korneplodov saharnoy svekly v usloviyah TsChR. Ramon'. Available at: https://earthpapers.net/razrabotka-sposobov-povysheniya-sohrannosti-massy-i-kachestvakorneplodov-saharnoy-svekly-v-usloviyah-tschr

18. Hranenie ovoschey. Available at: https://znaytovar.ru/s/Xranenie_ovoshhej.html

19. Koltunov, V. A. (2004). Yakist plodoovochevoi produktsiyi ta tekhnolohiya yii zberihannia. Ch. I: Yakist i zberezhenist kartopli ta ovochiv. Kyiv, 583.

20. Koltunov, V., Bielinska, Ye. (2010). Obhruntuvannia efektyvnosti zberezhenosti redysu metodom Kharrinhtona. Tovary i rynky, 2, 62-68. Available at: http://tr.knute.edu.ua/files/2010/10/12.pdf

21. Zherdetskyi, I. K. (2010). Osoblyvosti zberihannia matochnykh koreneplodiv. Propozytsiya: Informatsiynyi shchomisiachnyk, $11,82-84$.

22. Larsen, H., Wold, A.-B. (2016). Effect of modified atmosphere packaging on sensory quality, chemical parameters and shelf life of carrot roots (Daucus carota L.) stored at chilled and abusive temperatures. Postharvest Biology and Technology, 114, 76-85. doi: https://doi.org/10.1016/j.postharvbio.2015.11.014

23. Duarte-Sierra, A., Tiznado-Hernández, M. E., Jha, D. K., Janmeja, N., Arul, J. (2020). Abiotic stress hormesis: An approach to maintain quality, extend storability, and enhance phytochemicals on fresh produce during postharvest. Comprehensive Reviews in Food Science and Food Safety, 19 (6), 3659-3682. doi: https://doi.org/10.1111/1541-4337.12628

24. Otoni, C. G., Avena-Bustillos, R. J., Azeredo, H. M. C., Lorevice, M. V., Moura, M. R., Mattoso, L. H. C., McHugh, T. H. (2017). Recent Advances on Edible Films Based on Fruits and Vegetables-A Review. Comprehensive Reviews in Food Science and Food Safety, 16 (5), 1151-1169. doi: https://doi.org/10.1111/1541-4337.12281 